\title{
Legislators and their Oversight Functions in Policy Implementation in Nigeria
}

\author{
Ngozi Nwogwugwu ${ }^{1 *}$, Adebola Ishola ${ }^{2}$ \\ ${ }^{1}$ PhD Senior Lecturer at the Department of Political Science and Public Administration, Veronica Adeleke \\ School of Social Sciences, Babcock University, Ilishan-Remo, Ogun State, Nigeria. \\ ${ }^{2}$ PhD candidate at the Department of Political Science and Public Administration, Veronica Adeleke School of \\ Social Sciences, Babcock University, Ilishan-Remo, Ogun State, Nigeria.
}

\begin{abstract}
*Corresponding Author: Ngozi Nwogwugwu, PhD Senior Lecturer at the Department of Political Science and Public Administration, Veronica Adeleke School of Social Sciences, Babcock University, Ilishan-Remo, Ogun State, Nigeria.
\end{abstract}

\begin{abstract}
Legislatures are critical institutions in making a democratic system function going by the assumptions that democratic governance is now a preferred system of government in many parts of the world. The most important function of legislators is policy representation which requires the advancement of the interests of their constituents in policy process. In addition, legislators have the responsibility of representing the society through their oversight function. Through the oversight function, legislators see to it that the actions and spending of the executive and other agencies of government are in line with the constitutional allowance. However, there have observations that many policies that appear good on paper have failed to achieve the expected targets after implementation. This calls to question the execution of oversight functions by the legislators. The study examined the dynamics of the Legislators performance of oversight functions in policy implementation process by the executive in Nigeria. The study was qualitative and employed in-depth interview as the method of data collection. Fifteen legislators (eight senators and seven House of Representative members) were interviewed. Narrative interpretative approach was adopted in the analysis of data. The study concluded that interference by leadership of political parties and personal interests of the legislators hindered the performance of oversight function which resulted in failure to effectively implement public policies in Nigeria.
\end{abstract}

Keywords: Legislature, Policy Implementation, Public Policy, Oversight Functions

\section{INTRODUCTION}

One of the characteristics of government is its authority, ability and right to make, administer and enforce binding rules, laws and policies on the citizens in a legal manner. Normally, as soon as public officials and political office holders become aware of a problem in a society, they investigate and examine the areas in which government is not rendering the services it should render. Once that has been established, they begin to set out objectives of what is needed to take care of the problem and what resources are needed to achieve the desired objectives. These are all policy actions which will then be followed by setting out alternative policy options and the cost benefit of the different alternatives. The legislators are meant to be the middle men between the government and the public. Their roles are central in policy making process as they hold the government accountable in whatever decisions they make. This is the oversight function which they play which is so germane to government actions. The Legislators operate in a democratic system to make policies on national economy such as policy on education, housing, agriculture and security. They conduct 'check and balance' function through which they ensure that programs and policies of government are carried out legally, effectively and timely for the purpose they were intended. For example, they hire the policy actors together and ensure they conduct their duties responsibly. At the stage of the policy design, the goals, priorities, options, costs and benefits of each option, externalities of each option are all discussed and analysed. It entails identifying those who will be involved in the formulation of the policy, those that will be involved in the agenda setting of the policy, the participants in the adoption of the policy and those who will eventually implement the policy. The participation of all stakeholders in the policy process will determine the outcome of the policy (Hai, 2013). 
Legislators oversee government affairs, making sure of the compliance of all agencies and the executive in accordance with the constitutional directives that will lead to successful implementation of all policies. There is a growing pessimism about the effectiveness of public policies in many of the African nations as most of the policies have not translated into progress as these countries including Nigeria is faced with myriad of problems such as insecurity, poverty, unemployment, low standard of living among others. According to Ugwuanyi and Chukwuemeka (2013), over the years, Nigeria has formulated policies that appear to be brilliant on paper however the implementation had failed to redress the problems they set out to solve, serving as evidence of problem in the process. According to National Bureau of Statistics (NBS) of February 2018, 33.3\% of people in Nigeria are living under severe poverty while $52.0 \%$ are in poverty category as at late 2017 . In addition, the unemployment rate increased to $18.80 \%$ in the third quarter of 2017 from $16.20 \%$ in the second quarter of 2017 . The study was qualitative and utilized both primary and secondary data. The primary source in-depth interviews, which was conducted with 15 legislators (eight senators and seven House of Representative members). The study also employed documentary reviewof journals, newspaper, magazines, textbooks and relevant materials downloaded from the internet. Narrative/Interpretative approach was employed in the analysis of data. The different sections of the study were, introduction, literature review, theoretical framework, factors that affect performance of oversight functions, results and discussions, and conclusion.

\section{LITERATURE REVIEW AND CONCEPTUAL FRAMEWORK}

\subsection{Legislators' Role}

According to Heywood (2007), the role of the legislators varies from one country to another and from one system to another. But most importantly, the legislators irrespective of their names or place provide a link between government and the people. The role of the legislators in policy making is primarily to collate the views, interests, demands and problems of their constituents, harmonise and translate them to policy proposal for legislature. Such proposals are subject to the entire legislative processes after which it is presented to the president for ascent.

Nigeria operates a bi-cameral legislative system comprising the Senate and the House of Representative which is called the National Assembly. The national legislative authority in South Africa is vested in parliament, which consists of two houses: the National Assembly and the National Council of Provinces. As in many countries, the National Assembly under the Constitution is a body elected to represent the people and to ensure government of the people by the people (Kola-Olusanya, Omotayo\& Fagbohun, 2011).

As posited by Agba, Chukwurah \& Achimugu (2014) Nigeria operates a bi-cameral legislative system comprising the Senate of 109 members and the House of Representative with 360 members. It is called the National Assembly and it is the highest elective law-making body of the nation. The national legislative authority in South Africa is vested in parliament, which consists of two houses: the National Assembly and the National Council of Provinces. As in many countries, the National Assembly under the Constitution is a body elected to represent the people and to ensure government of the people by the people. The legislative mandate, they went further are those vital duties or constitutional stated roles of the legislators which are to enact, repeal, revise and review existing laws and regulations for the development and wellbeing of the citizens. The question however is, do the legislators perform their roles in policy process.

Ojo and Omotola (2014) stated that the legislatures or parliaments are at the heart of governance and the national integrity system that citizens entrust with the great task of making sure that states which practice democracy and are aided by the constitution fulfil their functions in the interests of the citizens. They further stated that though there can be government without the legislature, but there cannot be democracy without the legislature. In summary according to Popoola (2016), the role of the legislators in policy making is primarily to collate the views, interests, demands and problems of their constituents, harmonise and translate them to policy proposal for legislature. Such proposals are subject to the entire legislative processes after which it is presented to the president for ascent.

Legislatures can ensure greater accountability and transparency in issues of implementing national or public policies as this is in line with their three (3) main functions which are - legislative, oversight, representative and investigate. However, the focus of this study is on the performance of oversight functions by the legislators. 


\subsection{Oversight Functions}

Heywood (2007) explained that the oversight function can also be referred to as scrutiny. According to Cosmeus (2016), the primary role of the legislature in public policy process is that they are responsible for holding governments accountable in their decisions and they scrutinize the government in their actions. In recent times, the legislators have become increasingly a scrutinizing body of the executive so as to deliver responsible and accountable government. Shafritz, Russell and Borick (2016), explained that the oversight functions take many forms and the most common is the annual (in a place like the US) congressional hearings of agency's budget requests where agencies have to defend or justify their activities to the satisfaction of the Congress. At some other times, subpoena power may be used to summon reluctant agencies or public officials. The constitution in most places gives a legal backing to the oversight function of the legislature in which it can monitor the activities of the executive branch and its agencies to determine if public projects or programmes are being adequately executed. According to Saiegh (2014), the oversight function or role of the legislatures means ensuring the implementation of laws, ensuring that legislation and government policies are implemented effectively. Monitoring, reviewing and investigating programmes and activities of government to ensure that the actions taken are transparent, accountable and consistent according to the original intent as allowed by the constitution.

According to Frolick (2016), legislators have the legal backing, authority and responsibility to hold governments to account in their activities. Ojo and Omotola (2014) also posited that, legislators hold ministries, departments and agencies of government accountable in their activities to the public. Not only do they hold the executive accountable in their functions, they also have the power to approve or confirm appointments made by the executive and judiciary. Such appointments include that of ministers, chairmen, Ambassadors, Chief Justice of the federation, federal commissions and councils, justices of the supreme courts and the chief judge of the Federal High Court.

The legislators through their oversight function, rise up to ensure that funds appropriated for government institutions are utilised for the purpose they were allocated for to ensure that citizens get value for their money. According to Posner and Park (2007) the legislators' authority to appropriate public funds has been the foundation for public budgeting and accountability. The fundamental power of appropriation gave the legislature formative influence in allocating funds among competing priorities. And the varying influence of legislators in budgeting is reflected in the different political systems. For example, the prime minister in UK can be crossed examined once a week and the legislators can subject other senior ministers to similar scrutiny once a week if there is mismanagement in the federation's account (Heywood, 2007).According to Pelizzo and Stapenhurst (2004) in the presidential systems, the legislative oversight function is normally a routine of checks and balances which is part of separation of powers. Conversely, in parliamentary system, it may be politically difficult for legislative committee to question ministers since they are also members of parliament. In such cases a regularly scheduled question and answer period will serve the purpose by allowing opposition members to question the ministers, challenging the decisions of government on policies and programmes.

Ewuim, Nnamani and Eberinwa (2014) stated that the oversight function of the legislators is a major component of modern day legislature irrespective of the system of government. This according to Saliu and Muhammad (2010) as cited by Ewuim, Nnamani and Eberinwa means the legislative body takes active role in understanding and monitoring the performance of the executive arm and its agencies regularly. The principle behind this function of the legislature is to ensure that public policy is administered in accordance with the legislative intent. The oversight functions also involve watching and controlling the activities of government through general debates, questioning of ministers, agencies and other public officials. They can also conduct investigation of committees and where necessary impeach officers they find opposed to democratic performance in their activities. For example, section (1) (a-b) of the Nigerian constitution provides that each House of the National Assembly shall have power to direct or cause to be directed an investigation into any matter or thing with respect to which it has the power to make laws and the conduct of affairs of any person, authority, ministry or government department charged or intended to be charged, with the duty of or responsibility for executing or administering laws enacted by the National Assembly. This is so as to expose corruption, inefficiency or wastages in the execution of public programmes (Agba, Chukwurah \& Achimugu, 2014). 
The oversight role of the legislators according to Malapane (2016) is to ensure that the policies of government represent the needs of the people and the parliament, Congress or National Assembly and should be seen to be performing the role to the benefit of all citizens of the nation and this should be emphasised. Malapane went further to list the purposes of the oversight functions by the legislature: it is to improve the efficiency, economy and effectiveness of government operations; to evaluate programmes and performance; to investigate and prevent poor administration, to avoid waste, abuse of power, arbitrary and illegal and unconstitutional conduct, to protect civil liberties and constitutional rights and lastly to inform the general public and ensure that executive policies reflect public interest. The legislators have the power over the policy, budget, security issues, procurement of defence equipment, investigating the activities of the armed forces and the deployment of the military in a state of emergency. However, political system, constitutional and legal framework marginalize the role of the legislature to the executive in formulating and implementing policies in this regard. Legislators serve as overseers of the executive on behalf of the general public (Kotia, 2011).

According to Nwagwu (2014), the oversight function has been compromised by many legislators (especially in a place like Nigeria) and it now appears to preoccupy modern day legislators. It also appears as if this function is more important to the legislative assembly than that of law making functions as legislators now take this function more seriously than the law making function. In fact in many countries, legislators now use the oversight function to witch hunt and blackmail political opponents rather than use is to checkmate the excesses of the executive arm of government in order to curb or guide against corruption, inefficiency and waste of public funds.

\subsection{Policy Implementation}

This is a distinct stage in the policy process. This is the point according to Shafritz, Russell and Borick (2016) where the programme of the government is put into effect. It is the stage where the complete process of policy circle is translated into a legal mandate whether it is an executive order of an enacted statue. Heywood (2007) listed some conditions that are required to achieve a systematic perfect implementation strategy of policy. These are: a unitary administrative system with a single line of authority to ensure central control; uniform norms and rules that operate throughout the system; perfect obedience or perfect control; perfect information, perfect communication and perfect coordination; and sufficient time for administrative resources to be mobilized.

According to Mintrom (2019), policy implementation entails the followings: that policy actors must assign duties and responsibilities to those who will be involved in the process; the hiring and assigning those personnel that will be involved in executing the policy; it also entails the issuing and enforcing directives, disbursing of funds and resources that will be needed for the execution of the policy, signing contracts, data collection and analysis and to ensure that the programme of the government is put into effect.

These conditions are listed so as to help us understand why so many public policies fail to pass through to the stage of implementation. This is because there is often difficulty of achieving many of these conditions resulting in the gap between decision and delivery. Sands et al (2018) explained that implementation of policies go through some phases that must have been laid down by the state. The first is by adopting national implementing measures, secondly by ensuring that national measures are complied with by those policy makers within the jurisdiction of the policy and thirdly by fulfilling obligations to the relevant international organisations such as reporting the measures taken to give effect to the policy complying with international standard. Cloete, Wissink and De Coning (2010) explained that there is a great gap between the formulation stage of a policy and the implementation stage. They identified five critical variables in the implementation stage and these are:

Content: Cloete, Wissink and De Coning (2010), explained that policy is distributive, regulatory or redistributive. They went further to state that politics are determined by policies and government often employ coercion as the most significant political fact is that policy content is determined by the amount of and the extent to which government can coerce communities and societies. The importance of this is that policy content is not limited to the means used to achieve the objectives of the policy but how the goals are determined and the means of achieving the goals.

Context: Hallsworth, Parker and Rutter (2011) explained that some policies are meant to address specific areas such as economic, politics, social and legal issues. Therefore, policies implementers must pay attention to the contextual framework of each policy which might influence and impact on effective implementation processes. 
Commitment: When a government is committed to improving the well-being of its citizens according to Cloete, Wissink and De Conning (2010), implementing the policies formulated will be a priority in such a government agenda. The government will commit all it takes to implement whatever policy it has formulated for the benefits of its citizens that is, when such government can be termed efficient and effective.

Capacity: According to Ugwuanyi and Chukwuemeka (2013), successful implementation of a policy depends on the professional capability, skills, interest, abilities and attitude of the bureaucrats who are the main participants in the process. For example the knowledge of the public servants to deliver public policy goes a long way for effective policy implementation. Some of them do not have or possess the requisite manpower and financial resources to effectively implement the policies.

This stage as posited by Ugwuanyi and Chukwuemeka (2013) is the process of translating a policy into action which will invariably result in various projects and programmes. This is most often accomplished by different institutions other than those that formulated the policy. Most public policies are often carried out by administrative agencies in the executive branch. It requires according to Edet and Amadu (2014), determining the application, administration and effectuation of the policy. Nweke (2006) was quoted by Ugwuanyi and Chukwuemeka (2013) that policy implementation includes issuing and enforcing directives, disbursing of funds, signing contracts, data collection, collation and analysis. It also involves hiring and assigning those personnel that will be involved in executing the policy, setting up committees and commissions, assigning duties and responsibilities and making interim decisions.

According to Grimsley (2013), policy implementation stage is where those involved in the policy process must make sure they understand global issue and some identified problems that might affect domestic issues and what and who is needed to proffer solutions to those identified problems, making sure that they take care of all the factors and issues that might impinge on the success of the policy. Obo, Eteng, \& Coker (2014) stated that there are also many people that are involved in the process such as the public, NGOs and external forces. But the relationship between public opinion and public policy making process is a difficult one. The relationship between citizens and political/elected office holders in policy processes for example have been complicated and have resulted in the lapses observed in many of the policies and programmes of the government especially at the implementation stage.

Policy implementing stage is the phase when the policy is publicised and made to work. At this stage, the parameters of those the policies are meant for, the circumstances under which the policy statements are made and the directives, conditions and restrictions are all spelt out in clear statements. For example if a policy on vat on goods are enacted by the government, it is at this stage that the government will have to clearly state what kind of goods are exempted from vat and if and how one can get vat refund, when and where (Lohrey, 2018).

\section{THEORETICAL FRAMEWORK}

\subsection{Principal Agent Theory}

The theory and its major proponents:

Principal agent theory has its roots in Economics, where its original proponents Spence \&Zeckhauser (1971), applied the theory to the subject of insurance. However, further interrogation has revealed that the theory is central to understanding the effects of information asymmetries in several disciplines including public administration and political science (Gailmard, 2012; Bolton and Dewatripont 2004; West, 1997).

Principal-agent theory encapsulates a tradition of rational choice modeling, in which some actor(s) known as the principal(s) uses whatever actions are available, to provide incentives for some other actor(s) referred to as the agent(s) to make decisions that the principal most prefers.

In principal-agent models, some actor (or group of actors) called an agent undertakes an action on behalf of another actor (or group of actors) called a principal. The principal, for its part, can make decisions that affect the incentives of the agent to take any of its various possible actions (Gailmard 2012). This process of structuring incentives for the agent is the central focus of principal agent theory. The decisions made by the principal that structure the agent's incentives to take various actions constitute a contract, in the language of principal-agent theory, and principal-agent theory is often taken as a specific area of contract theory more generally (Bolton and Dewatripont 2004). 
West (1997) interprets the theory in the context of the control of the bureaucratic system of a given country by the legislature, using the United States as his study context. He writes that:

Principal-agent theory emphasizes the uncertainty and problems of accountability stemming from asymmetries of information that characterize congressional-bureaucratic relations, from changing political environments, and from the tendency of agencies to pursue their own agendas (West 1997: 597).

The proposition of West (1997) is that the legislative committees serving as principal exert some constraints on the bureaucracy (the agent) which ensures that the bureaucrats discharge their responsibilities in such a manner as to meet the needs of the society. This is in line with the context of this study, on the performance of oversight functions by the legislators. The legislative committees that carry out the oversight functions, ensure that the bureaucrats that work in the various ministries, departments and agencies, do not further their personal interests by shirking from the responsibilities assigned from them, or mismanage the resources entrusted to their charge.

Gailmard (2012) observes that Principal-agent theory has been regarded as a portent, flexible and useful approach for interpreting the effects of institutional arrangements on accountability of public decision makers and public policy.

The theory has been subjected to some criticisms. Gailmard (2012) argues that principal-agent theory is inappropriate for analyzing accountability of some actor to another, in situations where the second actor is not aware of his or her dependence on the first and/or cannot do anything to affect the behavior of the first actor. Principal agent theory has been charged with high level of flexibility. Critics argue that the theory provides explanation for all patterns of behavior within its domain of interest.

Proponents of the theory counter the critics by arguing that in spite of the presumed weaknesses, the principal-agent theory has proven to be a flexible and useful tool or mechanism for interpreting the effects of institutional arrangements on accountability of public decision makers and public policy. Continuing research shows that in spite of misgivings of critics, the theory adequately serves the purpose of analysis of actual behavior of political and administrative actors in government (Besley 2007, Gailmard and Patty 2007).

\subsection{Factors that Affect Legislators' Oversight Function in Policy Implementation in Nigerian}

According to Guide to Effective Representation in The National Assembly (2016), in a presidential system like Nigeria, oversight is usually exercised through specialised legislative committees. Oversight functions of the legislators include: identifying the inefficiency and waste in government such as extravagance, fraud and misuse of public funds as well as redirection, redistribution and/or restructuring; making sure that government agencies are carrying out public policy effectively; determining whether each of the parties responsible for administering the law fairly and properly are doing so throughout the state and having a very good knowledge and understanding of governmental programmes, actions and activities.

Saiegh (2014) pointed out that there are several factors that will help the legislatures to perform their constitutional public policy making role. These factors include the followings: the legislatures' knowledge about the on-going issues, the goals and interests of the legislatures, the extent of their powers in a democratic, presidential or parliamentary dispensation, the nexus and support between the legislatures and other arms of government, the interaction between the legislatures and their constituents, how well the legislatures perform their law making and oversight functions and the capacity provided by the executive. For example according to Eniayejuni and Evcan (2015) in 2012, the executive branch of the Nigerian government reduced the percentage of fuel subsidy leading to an increase in the pump price of petrol per litre in the country. This led to strike, shut down of government institutions and the economy of the nation was on a stand still. The National Assembly had to quickly meet with various stakeholders, citizens and government institutions to dialogue and broker peace; negotiating a reversal of that policy by the executive.

Agba, Chukwurah and Achimugu (2014), have asserted that the overall performance of the Nigerian legislators in accordance with their constitutional mandated functions and roles in public policies and programmes have fallen short of both national and international expectations. The ways public policies are implemented in Nigeria have been defective and as such have not been able to address some social challenges of the nation like poverty, unemployment, insecurity, lack of obedience to the 
rule of law by the executive, injustice, decay in the nation's infrastructures, communal conflicts and many other social ills plaguing the nation. The National Assembly has experienced many challenges in the last twenty years - $1999-2019$ from leadership problems to allegations of corruption, ineffectiveness accusations by the public and other challenges. According to Makinde (2005), it is not enough to formulate a policy, achieving the success and outcome lies in the implementation. Implementation problem is the widening gap between intentions and results. Many a time, policy actors pay little attention to the subject of policy implementation while it is taken for granted that once a policy is adopted by government, it must be implemented and the goals expected is achieved. These lapses and 'carelessness' often result in poor policy implementation. In the case of Nigeria, there are so many abandoned projects and well written policies that were not either implemented at all or not well implemented. Among the reasons that have been adduced for these are; lack of professional skills by the legislators (Popoola, 2016; Ewuim, Nnamani \&Eberinwa, 2014), personal interest of the legislators (Popoola 2016; Ojo and Omotola (2014), lack of involvement of all stake holders in public policy process and corruption (Eneanya, 2014; Yagboyaju, Ojukwu, Salawu and Oni (2016).

\section{Results AND Discussions}

\subsection{Research Question: What are the Effects of Legislators' Oversight Functions on Policy Implementation in Nigeria?}

\subsubsection{Responses from Legislators}

The legislators claimed they take active role in understanding and monitoring the activities and performances of the executive and its agencies for policy implementation. According to Hon. W, "the constitution has given the legislative arm the right to approve budget submitted by the executive. In doing this, they can either step up or step down any estimate submitted to the House. This has been used on many occasions by the executive arm to create confusion in the nation and draw sentiments from the citizens against the legislature". Another Legislator in a separate interview, stated that "it was the performance of their oversight functions by the executive during the budget presentation of the outgone year, by removing some estimate from one heading and putting them under a different heading. But the executive accused members of the national assembly of being corrupt" (Hon. Y). Public opinion sided with the propaganda of the executive, and the Legislators were condemned for their actions, which was carried out to ensure that the resources of the state are channelled to the most appropriate courses.

According to Senator M. B., (in an interview conducted at National Assembly complex, Abuja, December $9^{\text {th }}$ 2018) stated that "bureaucrats and political appointees do not like legislators in the aspect of the oversight function because people would not want the legislators to inspect their activities. This is because most of them fall short in their performances".

Legislators also ensure that public officials do not take advantage of the citizens or infringe on their fundamental human rights in the process of executive their official functions. As such, the legislators provide avenue for the writing and submission of petitions by citizens against government agencies and ministries that have defaulted. Hon. A. N. (in an interview at the National Assembly complex, Abuja on $11^{\text {th }}$ December 2018) stated that "we make available avenue for citizens to submit petitions either to our constituency offices or to our offices at the national assembly. There is a committee in charge of public petition and when the committee receives a petition, the aggrieved party and the presumed 'offender' are both invited to the House. The committee will set up a semi court session where the case will be heard. Anybody who is found culpable is sanctioned". Where the Petitioner needs to be compensated, the Committee of the Legislators will order the defaulting agency or ministry to pay such a citizen. This was corroborated by Senator D. K. (in an interview at National Assembly complex, Abuja on $12^{\text {th }}$ December 2018) who stated that "At this sitting, the guilty agency is invited and an informal court setting is put in place with a lawyer sitting as the judge over the matter. Whoever is found guilty is penalised and in many cases asked to pay compensation to the other. An example was given of a citizen that was brutally dealt with by a military officer". Usually, it is the agency where the public official serves that is ordered to pay compensation. The interventions of the Legislators had helped the abuse of power by public officials as well as reduce the incidences of infringement on the fundamental human rights of the citizens by public officials.

All legislators interviewed agreed that they inspect on-going projects through the Senate and House committees to ensure excellent execution of the projects and avoid inefficiency and waste. Members 
can belong to different committees to supervise government activities. And through this means we can carry out their oversight function. Legislators do on-the-spot assessment and supervision of government projects. "We invite contractors sometimes, we check agencies' books and we visit senatorial districts to perform on-the-spot assessment of all government projects. We also inspect how government agencies, ministries and departments have been spending their allocations" (Hon S. M.). One of the legislator - Hon. K. claimed he had just returned from inspecting the rail across Lagos and Abeokuta (Ogun state) axis. He claimed he rode on the train with the Minister of Works - Babatunde Fashola. Another legislator (Senator D. K. in an interview at National Assembly complex, Abuja on $12^{\text {th }}$ December 2018) stated that he just returned inspecting the on-going road construction along Ilorin/Ibadan road. The Legislators agreed that their inspection of those projects result in ensuring that the contractors comply with global standards in the execution of projects. They also ensure that unscrupulous public officials do not connive with contractors to execute low quality projects for personal gains.

According Hon S. M. (in an interview conducted at the National Assembly complex, Abuja on $12^{\text {th }}$ December 2018), Nigerian legislators are not allowed to perform their Oversight function the way it ought to be performed. "Sometimes, the leadership of the Political Party that controls the executive, contacts Legislators who are members of their political party to get them to provide reports that give clean bill of health to the agencies of the government that are not performing to expectation on the sentiment of party loyalty". In such instances, the interest of the nation are sacrificed for party interest. Another, impediment to the performance of oversight functions is corruption and seeking for pecuniary gains by some legislators. Senator M. A. (in an interview on the $11^{\text {th }}$ December 2018 at the National Assembly complex, Abuja) stated that some legislators meet officials of government agencies who settle them huge sums of money to give favourable reports, even when the evidence on the ground proves contrary.

\section{DisCUSSIONS ON THE FINDINGS}

From the result of the interview, it is evident that, members of the National Assembly believe they are performing their oversight function as it is expected. The legislators all express their satisfaction in being able to oversee the implementation of the policies that have been formulated in Nigeria by monitoring and controlling the agencies, ministries and departments that have been saddled with the responsibility. They all explained that policy formulation is the responsibility of experts, professionals, elected public officials and the implementation of the policy is the responsibility of administrative officers in government agencies and ministries. The legislators stated that there are about 92 committees or more in the House headed by different chair persons and each member belongs to a committee although no member can belong to more than five committees. They explained that the committees are the machineries that legislators use to oversee different sectors, ministries, departments and on-going projects. In addition the legislators explained that the committees are expected to monitor the activities of the executive and all government agencies and parastatals. The committees write a report and later submit their reports to the House for discussions on their observation of the performances of government actions, inactions and activities. Sometimes there might be need to invite a contractor, agency, ministry, department or parastatal that has defaulted for questioning. The legislature exercises control over government's expenditure by approving or disapproving what is expended. To this end, the legislators are in charge of the resources needed for the execution of governmental projects by any ministry of agency.

\section{CONCLUSiON}

The above discussion has shown the importance of the legislators in public policy process as they play significant double roles. One is representing the citizens before government and representing government before the citizens. The study has also shown the importance of deliberations, agreement and nexus between the three arms of government, between government institutions and between government and the citizens. The overall conclusion from the foregoing therefore reveals that the legislators have not lived up to the expectation of Nigerians in terms of their contributions in public policy processes. The legislators have not performed in policy decisions in the interests of the citizens that elected them. This is because though policies in Nigeria are often well written, there is still the problem of implementation and this is because the legislators do not involve every policy actor that should be involved in the policy process. It is expedient for legislators to identify problems, study the 
issues and problems, engage members of the public to be able to receive their inputs, formulate policies on these issues to resolve the identified and approved solutions designed for the problems.

\section{REFERENCES}

[1] Agba, M. S., Chukwurah, D. C. \&Achimgu, H. (2014). Politics and administrative responsibility in Nigeria: An assessment of Legislative mandate performance and executive implementation of public programmes. Accessed on the $17^{\text {th }}$ of July, 2018 from www.rcmss.com/214/JGGSDA-VOl.2-No1/Politicsand

[2] Bolton, P. and Dewatripont, M. (2004). Contract Theory. Cambridge, MA: MIT Press.

[3] Cloete, F., Wissink, H.,\&DeConing, C. (2010). Improving public policy: From theory to practice. Accessed on the $18^{\text {th }}$ of August, 2018 from https://books.google.com/books/about/imporving_public policy.html..

[4] Cosmeus, J. (2016). The primary role of the legislature in the public policy process is to.... https://brainy. com/question/2237164. Accessed on the $4^{\text {th }}$ of April, 2018.

[5] DeGroff, A. \& Cargo, M. (2009). Policy Implementation: Implications for Evaluation. Wiley Periodicals Inter-Science Journals 124, 47-60. Retrieved on the $12^{\text {th }}$ of June, 2018 from pdfs.semanticscholar.org/56d8/ ec822c155270eb.

[6] Eniayejuni, A. \&Evcan, N. S. (2015). Citizen's Participation: Between continuity and change in Nigeria. www. researchgate.net/publication/283828516..... Accessed on the $16^{\text {th }}$ of June, 2018.

[7] Eneaya A.N. (2016). Theory and practice of public administration. University Press, University of Ibadan.

[8] Ewuimi, N. C., Nnamani, D. O. \&Eberinwa, O. M. (2014). Legislative oversight and good governance in Nigeria National Assembly: An analysis of Obasanjo and Jonathan's administration. Journal of Arabian Research Society for Multidisciplinary Issues, Dubai. 3(6). 2315-7844. Retrieved on the $8^{\text {th }}$ of May, 2018 from www.arabianjbmi.com/RPAM.index.php.

[9] Frolick, C. T. (2016). Role of legislators in climate change: The case of South Africa. www.cpahq.org/cpahq/ cpadocs/ RoleofLegislatorsin.... Accessed on the $2^{\text {nd }}$ of August, 2018.

[10] Gailmard, S. (2012). Accountability and principal agent models. In Oxford Handbook of Public Accountability. Retrieved online on 03-09-2018 from http://www.law.berkeley.edu/files/csls/Gailmard__Accountability_and_Principal-Agent_Models\%281\%29.pdf

[11] Gailmard, S. and Patty, J. (2007). Slackers and Zealots: Civil Service, Bureaucratic Discretion, and Policy Expertise. American Journal of Political Science 51, 873-889.

[12] Gerston, L. N. (2015). What is Public policy and what is the legislature's role? Accessed on the $21^{\text {st }}$ of May,2018 from www.leg.state.nv.us/Division/Research/LegInfo/.....

[13] Hai, D.P. (2013). Process of public policy formulation in developing countries. www.politicipublice.ro/uploads/ public_policy_formulation.pdf Accessed on the 1st of March, 2018.

[14] Hallsworth, M., Parker, S. \& Rutter, J. (2011). Policy making in the real world. https://www.institutefor governent.org.uk/sites/default/files Accessed on the 20th of July, 2018.

[15] Heywood, A. (2007). Politics. ( ${ }^{\text {rd }}$ edition). Palgrave Macmillan publishers Ltd., England.

[16] Kotia, E. (2011). The principle and reality of legislative oversight in defence matters in liberal democracies: An empirical case. Journal of Alternative Perspectives in the Social Sciences 3(1), 57-71. Retrieved on the $8^{\text {th }}$ of May, 2018 from www.japs.org/upload/3._Kotia[1].pdf

[17] Lohrey, J. (2018). The five stages of the policy-making process. https://www.biztluent.com/info10040221- five-stages-policymaking.. Accessed on the $30^{\text {th }}$ of August, 2018.

[18] Makinde, T. (2005). Problems of policy implementation in developing nations: The Nigerian experience. Journal of Social Sciences, 11(1), 63-69. Retrieved on the $10^{\text {th }}$ of August, 2018 from www.krepublishers.com/ 02-journals/JSS/JSS-11-0-000-000-2005-Web/...pdf.

[19] Malapane, A. (2016). Parliament as the beacon of hope to the people. http://ulspace.u.ac.za/bitstream /handle/ 10386/malapane_holding_2016.pdf. Accessed on the 14 $4^{\text {th }}$ of August, 2018.

[20] Mintrom, M. (2019). Public Policy. Investing for a better world. Oxford University Press, USA.

[21] National Assembly: People's Assembly (2018). www.pa.org.za/organisation/national-assembly Accessed on the 4th of March, 2018.

[22] National Bureau of Statistics (2018). www.today.ng/topic/national-bureau-of-statistics. Accessed on the $21^{\text {st }}$ of June, 2018.

[23] Nwagwu, E. J. (2014). Legislative oversight in Nigeria: a watchdog or a hunting dog? www.iiste.org/ Journals/index.php/JLPG/article/..... Accessed on the $27^{\text {th }}$ of June, 2018. 
[24] Obo, U. B., Eteng, F. O. \& Coker, M. A. (2014). Public opinion and the policy making process in Nigeria: A critical assessment. www.cscanada.net/index.php/css/article/viewfile/4241/pdf. Accessed on the $18^{\text {th }}$ of April, 2018

[25] Pelizzo, R. \&Stapenhurst, R. (2004). Tools for Legislative Oversight: An Empirical Investigation. World Bank Policy Research Working Paper. 11 (1) 175-188. Retrieved on the $21^{\text {st }}$ of June, 2018 from https://openknowledge.worldbank.org/handle/10986/14143.

[26] Popoola, O. O. (2016). Actors in Decision Making and Policy Process. Global Journal of Interdisciplinary Social Sciences, 5(1), 47-51. Retrieved on the $30^{\text {th }}$ of April, 2018 from https://docplayer.net/43989318-Actors-in-decision-making-and...

[27] Posner, P. \& Park, C. K. (2007). Role of legislature in the budget process: recent trends and innovations. OECD Journal on Budgeting 7(3), 1608-7143. Retrieved on the $13^{\text {th }}$ of February, 2018 from, www.docplayer.net/202330-Role-of-the-legislature-in-the.

[28] Reynolds, A. (2013). Representation and Rights: The Impact of LGBT Legislators in comparative Perspective. Journal of American Political Science Association, 107(2), 259-274. Retrieved on the $29^{\text {th }}$ of May, 2018 from https://www.jstor.org/stable/43654014.

[29] Ross, A. (2012). Sustainable Development law in the UK: From rhetoric to reality? Published by Earthscan Routledge, New York.

[30] Roux, N. L. (2002). Public policy-making and policy analysis in /south Africa amidst transformation, change and globalisation: Views on participants and role players in the policy analytic procedure. Journal of Public Administration. 37 (4), 2263-3881. Retrieved on the 22 ${ }^{\text {nd }}$ of March, 2018, from https://repository.up.ac.za/bitstream/handle/2263/3881/Roux-public....

[31] Saiegh, S. M. (2005). The role of legislatures in the policymaking process. www.researchgate.net/profile/ sebastian_saiegh/.... Accessed on the $17^{\text {th }}$ of May, 2018 .

[32] Shafritz, J. M., Russell, E. W. \&Borick, C. P. (2016). Public Administration. (8 ${ }^{\text {th }}$ Edition). Pearson, Longman. New York, USA.

[33] South African Legislative branch - Government (2018). https://www.indexmundi.com/south_africa/ legislative_branch.html. Accessed on the $12^{\text {th }}$ of March, 2018 .

[34] The Legislative process/PMG. https://pmg.org.za/page/legislative-process. Accessed on the $12^{\text {th }}$ of March, 2018.

[35] The 1999 Constitution of the Federal Republic of Nigeria \& Fundamental Rights (Enforcement Procedure) Rules as amended, (2008).

[36] Ugwuanyi, B. I \& Chukwuemeka, E. O. (2013). The obstacles to effective policy implementation by the public bureaucracy in developing nations: the case of Nigeria. Kuwait Chapter of Arabian Journal of Business and Management Review, 2(7), Retrieved on the $24^{\text {th }}$ of June, 2018 from www.arabianjbmr.compdfs/KD_VOL_2_/6.pdf.

[37] Yagboyaju, D., Ojukwu, C., Salawu, M. \& Oni, E. (2016). Fundamentals of Politics and Governance. Concept publications limited, Lagos, Nigeria.

\section{AUTHORS' BIOGRAPHY}

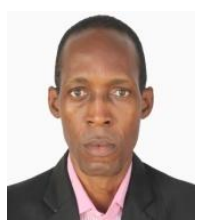

Dr. Ngozi Nwogwugwu, is a Senior Lecturer in the Department of Political Science and Public Administration, Veronica Adeleke School of Social Sciences, Babcock University, Ilishan-Remo, Ogun State. His areas of research interests include; Public policy and governance, African Politics, Gender studies; Environmental governance.

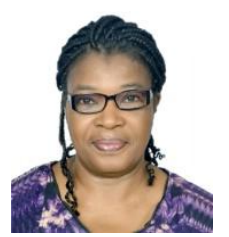

Mrs. AdebolaIshola, is a PhD Candidate, in the Department of Political Sciences and Public Administration, Veronica Adeleke School of Social Sciences, Babcock University, Ilishan-Remo, Ogun State. Her research interests cover: Policy studies, Gender studies, Environmental governance

Citation: Ngozi Nwogwugwu, Adebola Ishola. "Legislators and their Oversight Functions in Policy Implementation in Nigeria ". International Journal of Humanities Social Sciences and Education (IJHSSE), vol 6, no. 3, 2019, pp. 93-102 doi: http://dx.doi.org/10.20431/2349-0381.0603011.

Copyright: (C) 2019 Authors. This is an open-access article distributed under the terms of the Creative Commons Attribution License, which permits unrestricted use, distribution, and reproduction in any medium, provided the original author and source are credited. 